\title{
Analysing Parallel Interaction in Supply Chains: A Supply Chain Network Perspective
}

\author{
Elliot Simangunsong \\ Center for Asian Supply Chain Competitiveness \\ Prasetiya Mulya Business School, Jakarta
}

\begin{abstract}
ARTICLE INFO
Keywords:

Supply chain,

Parallel interaction,

Food industry,

Uncertainty management.

A B S T R A C T

Supply chain management refers to managing a serial chain of businesses which typically consists of retailer, distributor, manufacturer and supplier. However, the businesses in each tier also interact with other channels in the supply chain. These interactions are called parallel interactions and they can directly affect the traditional, serial interactions of a single supply chain. Serial and parallel interactions in a supply chain increase levels of complexity and uncertainty. As a result, it is important to move analysis from dyadic to supply chain network perspective to understand the issues better. The main objective of this study is to investigate parallel interaction issues and how it affects supply chain performance. An empirical study has been conducted in the food industry in Indonesia with inter-related companies. A two stages semi-structured interviews, with top executives from sampled companies have been conducted. The result of analysis helps to clarify previous studies and provide a better understanding of parallel interaction as a genuine source of uncertainty at supply chain level. Three strategies were also identified to effectively manage the issues caused by parallel interaction.

Corresponding author: elliot@pmbs.ac.id
\end{abstract}

\section{INTRODUCTION}

The business and its network of businesses have undergone significant changes in the last decade. This resulted in increased levels of complexity and uncertainty. For example, increased operations problems in terms of late deliveries, quality problems, lead time gaps, order cancellations, and the like. Currently, management of business operations is increasingly depended on collaboration with its business environment; it becomes more important and strategic (Riis, Johansen, Waehrens, \& Englyst, 2007). Wu et al. (2014) argue that collaborative behaviors in terms of systematic planning is a driving force of an effective supply chain practice. However, high dependency to other supply chain members make coordination on common terms difficult (McAdam \& McCormack, 2001) and major challenges 
includes alignment of all resources throughout the entire supply chain into focal organisations value propositions, to allow it excel in performance (Vachon, Halley, \& Beaulieu, 2009).

Complexity in a supply chain exists because of two unique characteristics within the boundaries of the supply chain. Firstly, number of components and type of organisations involved in a supply chain. Secondly, the interdependence nature of interactions between components that is potentially produces complex behaviour (Amit, Soundar, Mark, \& Nandini, 2005). These two factors create supply chain dynamics, with various uncertainties facing the members over time such as the level of customer demand or available capacity. Figure 1 shows generic supply chain model that contains up to three echelon levels. There are two streams of transformation process along the chain i.e. material flow forward and information flow going backward (Lambert \& Cooper, 2000). In general, each echelon consists of several components e.g. focal organisation, multiple suppliers, multiple wholesalers, multiple retailers, multiple customers, etc. However, by increasing the number of echelons or components in the chain, the complexity of the supply chain will increase significantly (Beamon, 1999). Another issue that add degree of complexity, with focal company chain as an example, is that members of the chains e.g. supplier may not only serve one supply chain but also serve other customers and their supply chains. Despite these challenges, Thun et al. (2011) argues that companies must realise the potential of relationships with suppliers as well as customers in a global context.

For this research, the unit of analysis is generally explained as first tier supply chain (see Figure 1). First tier supply chain means management of a chain of businesses which may consists of supplier, manufacturer as the focal organisation and customer. The suppliers may also interact with other channels in the supply chain. These interactions are called parallel interactions (Wilding, 1998) and they can directly impact the

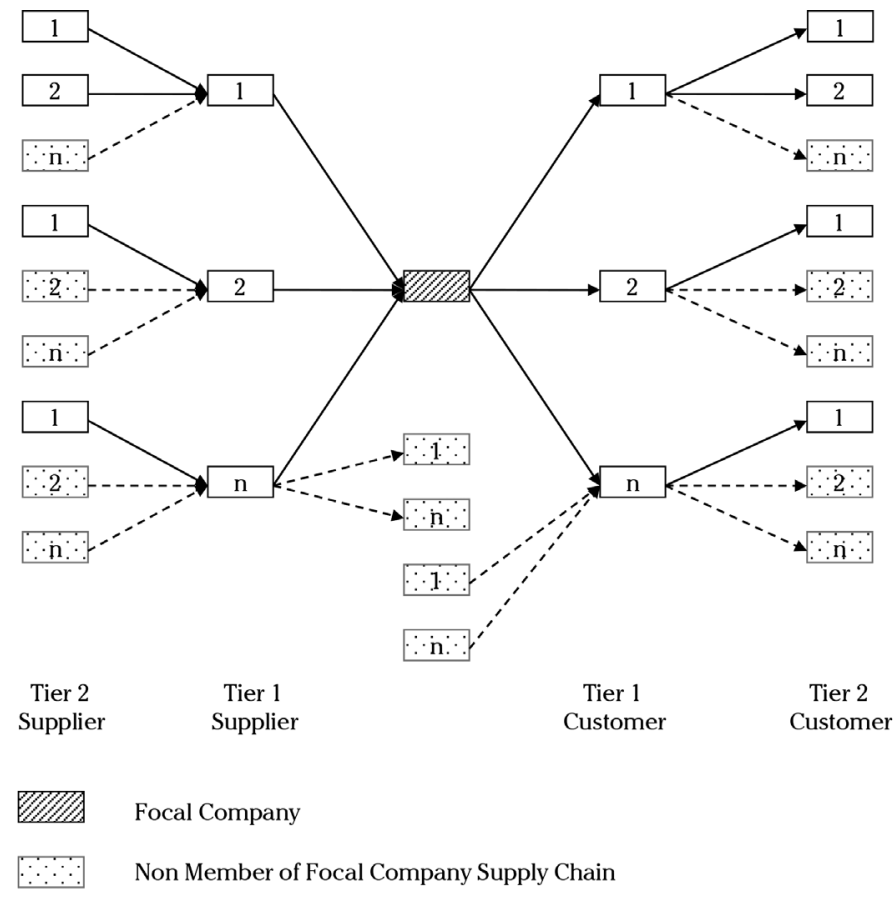

Figure 1. Supply Chain

Source: Adapted from Lambert and Cooper (2000) 
traditional, serial interactions of a single supply chain. Parallel interaction refers to the situation where there is interaction between channels of the supply chain in the same tier (Wilding, 1998). This interaction generates uncertainty within the supply network. For example, when a first tier supplier has problems to supply its customer, the customer then has to coordinate and make order revisions with other first tier suppliers. Parallel interactions can be buffered with increased inventory within the supply chain.

The objectives of this research are to explore parallel interaction in detail and how it disrupts businesses in practice. Literature is reviewed thoroughly to gain understanding of researches to date and to provide conceptual background. Recent studies, however, such as a study by Shou et al. (2013) suggests that few researches focus on managing the roles of supplier-buyer relationship in terms of how this influences attitude, patterns and practices. Another study by Hearnshaw \& Wilson (2013) suggests that the knowledge and perspective of the supply chain network theory is immature because the literature is limited and only has few examples. Further studies are still needed to develop general knowledge by deeply looking into the complex supplier-buyer relationship to help companies balance their position well in the supply chain and make the chain collaborate smoothly.

\section{Literature Review}

The development of theory in supply chain management field has been long been conceived as relational or dyadic terms. Most research considered the notion of chains of just two links: supplier to focal form, and focal firm to customer. Although research in this area is still rich, a new focus on supply chain network is beginning to supplant that of a simple chain. Moving the analysis from dyadic to network enlarges the scope of contextual factors and increases the variety of possible outcomes pursued within a supply network (Pilbeam, Alvarez, \& Wilson,
2012). Supply network is a chain of value through a network of firms, which may consists of persons, companies, or even countries. Hearnshaw \& Wilson (2013) added the importance of three types of flow i.e., material flows, information flows and financial flows when analysing exchange relationships in this supply chain network. Kim et al. (2011) suggests that it is increasingly important to to study this network structure of supply relationships. Analysing modern supply chain using linear conception of sequential dyadic relationships is considered not sufficient anymore (Hearnshaw \& Wilson, 2013).

Studying supply chains as networks requires a new understanding about their their underlying structure, properties and types of interactions. Hearnshaw \& Wilson (2013) divides supply chain networks into two categories i.e., a regular network model and a random network model. A regular network model has a regular topology characterised by a serial set of connections between nodes. A random network model has a random set of connections between nodes, nonlinear and dynamic. The nodes are interdependent where small changes may influence the network (Bellamy \& Basole, 2013).

A random supply chain network can be initiated by, for example, an extensive use of sourcing from multiple suppliers. Hesping \& Schiele (2015) explains that sourcing technology-based material from many suppliers stimulating competition for technological innovations that brings benefit to the company. Sheffi (2001) gave another example, the Toyota case, where in order to mitigate major disruptions (for example in terms of terrorist attacks or government blockades) Toyota develop multiple suppliers relationship involving local and global suppliers to maintain resilience on their supply chain. Toyota apply a strong relationship with some global suppliers; these are their prime supplier, but also ensuring that a larger number of loosely coupled relationships with local suppliers are also maintained as an alternative source of 
supply in case of a major disruptions.

However, as discussed later in the research findings, having a complex supply chain networks also caused negative supply chain performance, for example the parallel interaction issues which is difficult to be addressed.

It is to be noted that the available literature on understanding and developing the supply chains networks theory is limited (Hearnshaw \& Wilson, 2013). It is reasonable to assume that actively pursue ideas from different field of knowledge may help to develop and extend the knowledge and perspective of the supply chain network theory. Here, Hearnshaw \& Wilson (2013) suggest to incorporate social network analysis approach. The social network analysis, a sociology field of discipline, analyse interactions among large numbers of network nodes allowing better understanding into how interventions in one part of the supply chain may affect another part (Borgatti \& Li, 2009; Kim et al., 2011).

The study by Carter et al. (2007) also suggest the importance of social network theory from sociological field to help explain phenomena of collaboration or competition behaviours of players in a supply chain network. Moreover, Borgatti \& Li (2009) also noted that supply chain management not only has a hard/technical aspects, but also soft/ people aspects. The soft aspect of supply chain management is considered important in analysing interactions in complex supply chain, thus the importance of social network theory or analysis.

Social network theory is one of nine theories in emerging supply chain issues as discussed in the study by (Sarkis, Zhu, \& Lai, 2011). They argue that this theory helps to understand complexity of a system and indentifying ways to better managed them. The term "network" is a common keyword in supply chain management research; it describes supply chains as a network for firms that work together to gain better performance, operational effciencies, and competitiveness in the market. In social network theory, organisational performance is a result of social relationships between organisations or individuals in a network (Jones, Hesterly, \& Borgatti, 1997). This social network provides information and influence to decisions of an organisation. These social relationship can be friendship among employees in different organisation, intense of communication, workflow collaboration and transactions of goods and services.

Carter et al. (2007) identified that organisations are increasingly compete on their ability to manage networks within firms either formal or informal and the knowledge to influence the network. Without collaborative relationships and mutually beneficial partnerships among members of supply network, it is difficult to compete profitably (Huang, Yen, \& Liu, 2014). (Lazzarini, Chaddad, \& Cook, 2001) found that economists and strategy scholars have started to use social network approach in analysing networked-based industry performance. Managing Network externalities can be a source of value. Supply chain studies which focus on the entire supply network rather than isolated supplier-buyer relationship are increasingly gained important consideration in the supply chain field of knowledge (Choi, Dooley, \& Rungtusanatham, 2001; Olsen \& Ellram, 1997; Pilbeam et al., 2012).

From a supply network perspective, the relative position of individual firms with respect to one another influences both strategy and behaviour. The ability to coordinate internal activities with external supplier networks is one of the most critical strategic weapons for many successful organizations. Supply network can be a source of value if managed effectively. (Katz \& Shapiro, 1985) gave an example of a computer manufacturer that gain benefits by promoting interfirm coordination among its suppliers to capture value and opportunity for innovation generated from information sharing. This is because the main computer products is heavily depended on 
computer spare parts and their supplementary spare parts. Here, using a network perspective, difference knowledge among suppliers is beneficial because through coordination, it enables knowledge spillovers, which in turn, enhance opportunities for innovation (Lazzarini et al., 2001). Figure 2 presents an example of such supply network. This serial interaction among supply chain member in the same tier is called parallel interaction (Wilding, 1998).

Parallel interaction is one of the phenomena commonly occurs in a supply network (Wilding, 1998; Vorst \& Beulens, 2002; Prater, 2005). Here, suppliers supply different products to a company and there is interaction among them. A study by Blecker et al. (2005) identified that "non synchronized decisions and acting" is one of the driver of parallel interaction. Non synchronized decisions and acting across supply chain members create complexity in the involved companies due to discrepancies with former planning and scheduling process. Complexity theory defines a complex system as a system whose outcomes are unpredictable. One cannot know what the outcome of a system will be because of the effect that small changes have on the entire system (Webb, 2007). Uncertainty and interdependence (called as parallel processing) can be used as the dimension of supply chain complexity (Wilding, 1998). Another study by (Achrol, 1997) explain that multiple players in a business network introduce a greater range of possible relational dynamics that may inherit from, for example, on difference in organizational size, expertise and competency. Typically these relational dynamics are underpinned by differences in power relations and trust between actors as identified for supply chains (Barratt, 2004). Transport network management can be another significant source of parallel interaction. There can be integration and collaboration issues because of lack of communication between transport providers (Choy et al., 2007). When hauliers integrate their transport flows in series, major delays in the process can have a much more significant impact than if hauliers integrated parallel transport flows (Rodrigues, Stantchev, Potter, Naim, \& Whiteing, 2008).

This research names this type of interaction as general parallel interaction issues. Note that few studies have proposed and discussed viable strategies for this type of problem. This is inevitable given that few authors have identified this source of uncertainty. Moreover, the studies by Wilding (1998), van der Vorst \& Beulens (2002), and Prater (2005), discussed above, did not provide empirical evidence to support their argument.

Another type of parallel interaction is suppliers which potentially supply a similar product to

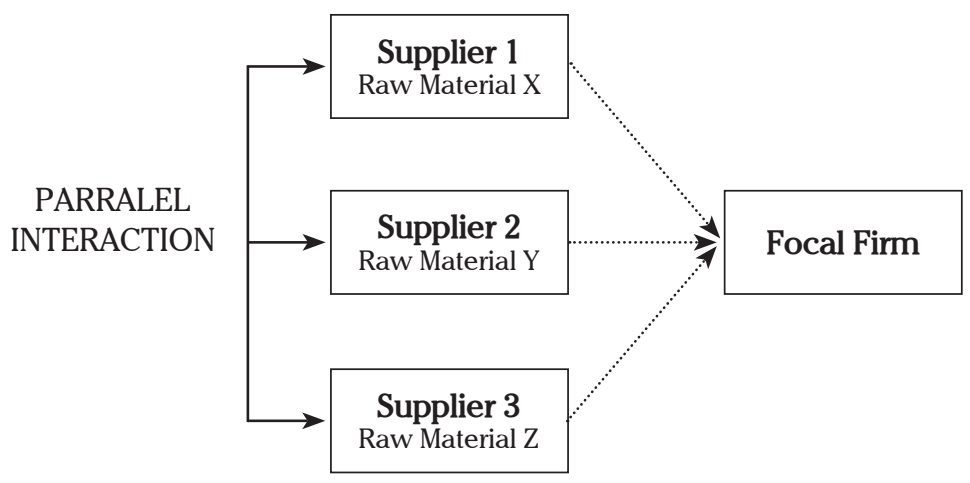

Figure 2. First type of Parallel Interaction 
customers act together, leading to uncertainty for their customers (see Figure 3). Two situations may give rise to this issue. The first situation is related to a specific product where the market has many buyers but a single or few suppliers are available and these suppliers control the market (Shou et al., 2013). This creates buyer dependencies which allow suppliers to exert power and increases buyer exposure to risk (Smeltzer \& Siferd, 1998). The second situation is related to commodity products, where suppliers tend to speculate in the market. This research names this type of interaction as collusion among suppliers. As discussed later, this second type of parallel interaction tends to negatively affect the buyers and tendency of abuse of power among different tiers in a supply chain. Levy (2008) noted that power issues are inherent in global supply networks where conflict and competition often occurs rather than cooperation.

Collusion among suppliers may occur because of imbalance of power among tiers in supply chain. A Irm's power with respect to its customer or supplier may stem from several factors, i.e., the number of major customers, market share, the number of potential suppliers for a given item, and the amount of revenue a company gets from a single buyer (Krajewski, Wei, \& Tang, 2005). Another important source of power is possessing or controlling a scarce resource (Ireland \& Webb, 2007; Shou et al., 2013).
The concept of power in a supply chain has been discussed in the literature. For example, Cox (1999) emphasised the importance of controlling supply chain resources which enable a company to build competitive advantage. Usually the opportunities to exercise systematic control of a supply network is reside in the most powerful player (Pilbeam et al., 2012). An example was provided, the Toyota case, where its dominant power relationship with its suppliers had allowed Toyota to force the innovations and control it desired from its supply chain partners. Dominant power in a supply chain may also negatively affect supplier-buyer relationships. Quayle (2003) identified how UK Industrial SMEs were victimised by customers that have strong power. Hingley (2005) and Taylor (2006) discuss more specific examples from the UK food industry where large multiple retailers hold the majority of control in the supply chain and has caused struggles in the food producers and manufacturers to survive. Munson et al. (1999) found similar issue in the USA industry where Wal-Mart and General Motors demand "rock bottom" prices or squeezed margins from their suppliers. These previous studies, however, did not refer to the issue of collusion, which is discussed in this section. They were mainly conceptual; the objective was to provide a general framework of parallel interaction that resides in a supply chain. Moreover, external environmental factors such as uncertainty were mostly studied

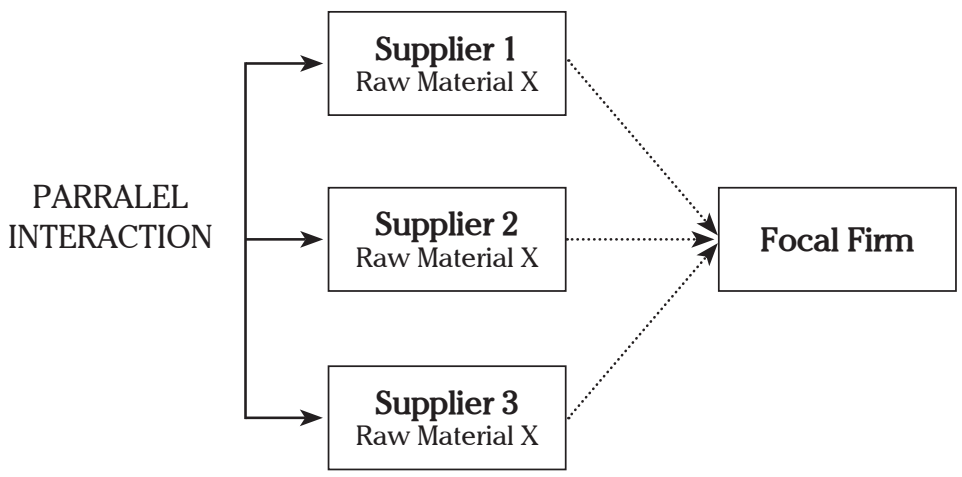

Figure 3. Second type of Parallel Interaction 
in dyadic relationships, few extend the analysis to supply networks (Pilbeam et al., 2012). Even the terminology "parallel interaction" is still not widely used. Hence it is reasonable to suggest that additional empirical research is required to strengthen the arguments and further develop understanding of this phenomenon. This leads to an important research question to explore what sources of parallel interaction can be identified in practice and how can they be managed.

\section{METHODS}

This research followed the 5 steps of the case research process adapted from the work of Stuart et al. (2002), i.e., development of research questions, followed by instrument development data collection, data analysis, and dissemination. Case research was selected over other research methods because research about parallel interaction is a complex and multi-faceted phenomenon; a rich set of data is required for analysis. This study also requires comparisons across organisations that may have different contexts (e.g. supplier versus manufacturer) to address research questions related to the issues of parallel interaction. It is likely that perceptions and interpretations of questions by individuals will affect how they answer a question. Here, face-to-face interviews using a pre-defined questionnaire will arguably produce more valid data and are more suitable than a less personal long distance postal questionnaire where the researcher is not present (Creswell, 2003). In addition to the above, Stuart et al. (2002) explained that research in operations management, including supply chain management, generally deals with complex systems which make generalizations that are difficult to test and validate.

Case research is primarily a qualitative research method and typically uses multiple data collection methods such as interviews (primarily), observations, questionnaires, reports, business plans, organization charts, and other secondary data (Meredith, 1998; Eisenhardt, 1989). Multiple data collection methods enable researchers to better understand the research context through triangulation; triangulation with multiple means of data collection increases the validity and reliability of research outcomes (Yin, 2003; Onwuegbuzie \& Leech, 2007). Ellram (1996) argues that case research is one of suitable research design for supply chain management.

A comprehensive literatures review has been done to investigate studies on parallel interaction in supply chains and how it is managed. This followed by an empirical study by employing case study research (see for e.g., Eisenhardt \& Graebner, 2007) in food industry in Indonesia to enable a better understanding and to extend the knowledge further. Food industry is selected because of its inherent complex network. For example, a study in the food industry by Holweg \& Pil (2008) found that food supply chain consists of an interconnected system with a large variety of relationships. In an food supply chain, more than one supply chain and more than one business process can be identified, both parallel and sequential in time. As a result, organisations may play different roles in different chain settings and therefore collaborate with differing chain partners, who may be their competitors in other chain settings. Maloni \& Brown (2006) find that the food industry is an extremely complex supply chain, where the path of a specific food product may vary. Reiner \& Trcka (2004) also find that supply chains within the food industry have different structures from each other, which required detailed analysis in evaluating the possible improvements of the supply chain.

A questionnaire has been developed to address the research objectives. A two stage empirical study has been conducted in the food industry in Indonesia, firstly by interviewing with 32 middle managers from twelve inter-related companies. These invited companies are coming from food manufacturers, their upstream and downstream channel in supply chain. Table 1 presents the 
profiles of respondents and their companies. The second stage is by focus group discussion with 7 top executives from seven companies, also in the food industry. Table 2 presents the profiles of the interviewees and companies. The organisations selected for analysis in these case studies are from a range of business sectors, and vary in size. The seniority of the interviewees means that it is reasonable to assume that they have knowledge or opinions regarding the research questions.

The interview was audio recorded and video recorded. Three research assistant helped to take notes during the discussion and later finalized the data. Where necessary, a follow-up telephone call or email was conducted with the interviewee to clarify vague or ambiguous responses. All of the data was then compiled into a case study database in Atlas.ti, which is a qualitative data analysis software package.

In this research, the interview questions were a series of predetermined but open-ended questions, as suggested by Ayres (2008) for semi-structured interviews. The interview questions were tested in a pilot interview with three interviewees: a director of food manufacturer and two senior researchers. The objective of the pilot was to test and develop the interview protocol. Following the pilot, several improvements were made to the interview questions to make the protocol more concise and the questions easier to understand.

For the purpose of this study, it is important to select companies that represent many parts of the food supply chain. Selecting companies that

Table $1.1^{\text {st }}$ Stage Interviewee and Company Profiles

\begin{tabular}{|c|c|c|c|c|c|c|c|}
\hline Companies & $\begin{array}{c}\text { Number of } \\
\text { Interviewees }\end{array}$ & $\begin{array}{l}\text { Managerial } \\
\text { Position } \\
\end{array}$ & $\begin{array}{l}\text { Type of } \\
\text { Company }\end{array}$ & Established & Headquarter & $\begin{array}{l}\text { Number of } \\
\text { employees }\end{array}$ & $\begin{array}{l}\text { Sales (Year) } \\
\text { in billion Rps }\end{array}$ \\
\hline $\begin{array}{l}\text { Supplier of } \\
\text { chocolate }\end{array}$ & 2 & Manager & $\begin{array}{l}\text { Multi } \\
\text { National }\end{array}$ & 1996 & Jakarta & 265 & $180(2008)$ \\
\hline $\begin{array}{l}\text { Supplier of } \\
\text { Plastic Packaging }\end{array}$ & 3 & Manager & National & 1959 & Tangerang & 4000 & $1600(2010)$ \\
\hline $\begin{array}{l}\text { Supplier of } \\
\text { Carton Packaging }\end{array}$ & 2 & Manager & $\begin{array}{l}\text { Multi } \\
\text { National }\end{array}$ & 1976 & Jakarta & 1000 & 4298 (2009) \\
\hline Supplier of Flour & 2 & $\begin{array}{l}\text { Manager, } \\
\text { Director }\end{array}$ & National & 1971 & Jakarta & 3000 & 101500 (2012) \\
\hline $\begin{array}{l}\text { Manufacturer of } \\
\text { Ice Cream }\end{array}$ & 5 & $\begin{array}{l}\text { Manager, } \\
\text { Director }\end{array}$ & National & 1973 & Surabaya & 800 & 650 (2012) \\
\hline $\begin{array}{l}\text { Manufacturer of } \\
\text { Healthy Drinks }\end{array}$ & 3 & Manager & National & 1978 & Jakarta & 1100 & 700 (2008) \\
\hline $\begin{array}{l}\text { Manufacturer of } \\
\text { Dairy Products }\end{array}$ & 3 & Manager & $\begin{array}{l}\text { Multi } \\
\text { National }\end{array}$ & 1971 & Jakarta & 2000 & 200 (2008) \\
\hline $\begin{array}{l}\text { Manufacturer of } \\
\text { Bakery }\end{array}$ & 3 & Manager & $\begin{array}{l}\text { Multi } \\
\text { National }\end{array}$ & 1996 & Jakarta & 700 & 1190 (2012) \\
\hline Supermarket & 3 & Manager & $\begin{array}{l}\text { Multi } \\
\text { National }\end{array}$ & 1998 & Jakarta & 11000 & 8000 (2008) \\
\hline Wholesaler & 4 & $\begin{array}{l}\text { Manager, } \\
\text { Director }\end{array}$ & $\begin{array}{l}\text { Multi } \\
\text { National }\end{array}$ & 1992 & Jakarta & 1700 & 3700 (2008) \\
\hline Mini Retail & 1 & Manager & National & 1991 & Jakarta & 5 & $0.5(2010)$ \\
\hline Traditional Store & 1 & Owner & National & 1978 & Jakarta & 3 & $0.36(2008)$ \\
\hline
\end{tabular}


Table 1. $2^{\text {nd }}$ Stage Interviewee and Company Profiles

\begin{tabular}{|c|c|c|c|c|c|c|c|}
\hline Companies & $\begin{array}{c}\text { Number of } \\
\text { Interviewees }\end{array}$ & $\begin{array}{l}\text { Managerial } \\
\text { Position }\end{array}$ & $\begin{array}{c}\text { Type of } \\
\text { Company }\end{array}$ & Established & Headquarter & $\begin{array}{l}\text { Number of } \\
\text { employees }\end{array}$ & $\begin{array}{l}\text { Sales (Year) } \\
\text { in billion Rps }\end{array}$ \\
\hline $\begin{array}{l}\text { Supplier } \\
\text { of Plastic } \\
\text { Packaging }\end{array}$ & 1 & $\begin{array}{l}\text { Division } \\
\text { Head }\end{array}$ & National & 1959 & Tangerang & 4000 & $1600(2010)$ \\
\hline $\begin{array}{l}\text { Manufacturer } \\
\text { of Frozen } \\
\text { Processed Food }\end{array}$ & 1 & Director & National & 1985 & Jakarta & 2323 & 4029 (2011) \\
\hline $\begin{array}{l}\text { Manufacturer } \\
\text { of food and } \\
\text { beverage }\end{array}$ & 1 & Director & National & 1958 & Jakarta & 18000 & 7687 (2012) \\
\hline $\begin{array}{l}\text { Manufacturer } \\
\& \text { Distributor of } \\
\text { Imported Food }\end{array}$ & 1 & Director & National & 1986 & Jakarta & 1000 & 7498 (2012) \\
\hline $\begin{array}{l}\text { Third Party } \\
\text { Logistics }\end{array}$ & 1 & $\begin{array}{l}\text { General } \\
\text { Manager }\end{array}$ & National & 2005 & Jakarta & 500 & 148 (2012) \\
\hline $\begin{array}{l}\text { Third Party } \\
\text { Logistics }\end{array}$ & 1 & $\begin{array}{l}\text { General } \\
\text { Manager }\end{array}$ & $\begin{array}{c}\text { Multi } \\
\text { National }\end{array}$ & 1992 & Jakarta & 500 & $\mathrm{~N} / \mathrm{A}$ \\
\hline $\begin{array}{l}\text { Traditional } \\
\text { Market }\end{array}$ & 1 & Director & National & 2006 & Jakarta & 150 & $\mathrm{~N} / \mathrm{A}$ \\
\hline
\end{tabular}

represents supplier, manufacturer, distributor and retailer bring many advantages, i.e., it facilitates richer data analysis, providing data triangulation, and is important in gaining a better understanding of the phenomenon being studied.

\section{Empirical Analysis}

A supply chain of large businesses tend to be a complex system, as identified in this study. The supply networks consists of collection and interaction of many elements that impact qualities, process, functions, behavior, and supply chain performance. The case study evidence suggests that the two types of parallel interaction - general parallel interaction issues and collusion among suppliers - exist in the Indonesian food supply chain. From the first stage interview with practitioners in the food supply chain, qualitative data analysis had been done to investigate specific parallel interaction issues and how these affected the respected companies. This will be explained below. Analysing data from the second stage of interview - focus group discussion with top management in the food industry - had helped to enable further understanding and confirmation from the point of view of decision makers in the industry.

The first type of parallel interaction - general parallel interaction issues - was identified in the plastic packaging supplier. Here, the customer of the packaging supplier rejected delivery because its other suppliers was not ready to deliver raw material at the promised time. For the plastic packaging company, this issue had caused bottlenecks in the production line and disrupted their production plan. Moreover, plastic packaging is a bulky product; this may increase logistics costs, for example in terms of additional holding costs. Focus group discussion of seven top decision makers were also confirmed this type of parallel interaction. The director of frozen processed food summarised that the issue often occurred because rejection of incoming material, either in warehouse or production facility was a common business practice. Lack of ethical 
business practice and regulation were agreed as the major reason. The other case companies did not report this issue as being of particular concern for the following three reasons. Firstly, the case companies supply products which do not have any parallel interaction, as in the cases of the manufacturers supplying food to the retailers. Secondly, the supplied product is not bulky; hence there are no storage problems, as in the case of the plastic packaging supplier. Thirdly, the case companies have strong bargaining power and are able to press customers to bear the consequences of parallel interaction, as in the cases of the carton packaging supplier and the flour supplier. The plastic packaging supplier, which was facing general parallel interaction issues was identified of using collaboration strategy to reduce the impact. Previously, the study by van der Vorst \& Beulens (2002) has suggested this strategy albeit without providing empirical evidence.

The second type of parallel interaction, i.e. collusion among suppliers, was identified in five case companies (supplier of flour, manufacturer of ice cream, manufacturer of healthy drinks, manufacturer of dairy products, and traditional store). Here, suppliers which potentially supply a similar product to customers act together, leading to uncertainty for their customers. Two situations may give rise to this issue. The first situation is related to a specific product where a single or few suppliers are available and these suppliers control the market. For example fibres as a raw material for food manufacturer, where few suppliers are available and they control the market. Analysing empirical data show indication that these suppliers worked together (cartel) in supply and price games for their advantage and thus created uncertainties (supply availability and price) that had caused disruption in the supply chain processes, for example, in terms of an inability to meet production targets and varied production costs. Another example was collusion of truck manufacturers association in setting price and truck availability, as discussed in focus group discussion. The second situation is related to commodity products such as wheat, sugar, and raw milk where suppliers tend to speculate in the market. For example, the production manager of the ice cream manufacturer experienced collusion among suppliers (sugar producers) where suppliers deliberately hold stock in their warehouses and create an illusion of scarcity of sugar in the market for a temporary period in order to induce a price increase. This issue had disrupted their production plans because sugar is one of the main raw materials for ice cream. A similar situation was also found in the dairy manufacturer and the flour supplier.

Analysis of focus group discussion data suggest unethical business practices was common problems in buyer supplier relationship in Indonesia, such as, volume games, industry association taking advantage of strong bargaining position, cartel of importer of commodity material (for example milk imported from New Zealand), price fixing for sea transportation, and weak government role to establish fair business practices. These top management executives agreed that collusion among suppliers was a critical issues and difficult to manage.

However, the case study evidence also suggests that collusion among suppliers may not arise if either of two possible circumstances exists. Firstly, collusion does not succeed if the case company has strong bargaining power. For example, the bakery manufacturer is the major player in Indonesia and they buy commodity products in large quantities. Here, suppliers are keen to have their business and hence suppliers always compete to win orders. Secondly, collusion will be ineffective if the case company is able to source from a supplier which is not part of the cartel. For example, the dairy manufacturer in this study stated that they have been able to obtain permission from the government to import sugar for a temporary period. This has enabled the dairy manufacturer not to source sugar from the 
local cartel. Normally, the Indonesian government tends to protect local sugar producers, hence special permission is required to import sugar from foreign countries.

Four companies (supplier of plastic packaging, supplier of flour, manufacturer of healthy drinks, and manufacturer of dairy products) were using three strategies for managing collusion among suppliers. The first strategy is collaboration. Here, companies in the same industry initiate industry association and then lobbying the Government of Indonesia. This lobbying effort, for example regulation of sugar, is effective in persuading the government to open the door to allow sugar to be imported into the country, hence providing better raw material availability and lower purchasing price (the locally produced sugar is more expensive). However, strong protests from local farmers and sugar producers may then lead the government to cancel that policy. The second strategy is group purchasing, as in the case of the healthy drink manufacturer. The healthy drink manufacturer initiate joint buying with purchasers from same industry area. Joint buying increases the order volume for one purchase and forces suppliers to break from the cartel because each cartel member wants to win the order. Group purchasing has positively affected performance, for example in terms of purchasing price, raw material availability, and delivery responsiveness. The third strategy is multiple suppliers, identified in the traditional store. Here, sourcing from suppliers in different regions increases transportation cost, and hence reduces profits. However, the strategy means that the store is at least able to satisfy its customers during the period.

Parallel interaction is a difficult problem to manage and is arguably a genuine source of uncertainty at a supply chain level; all the strategies discussed above require supply chain coordination or have knock-on effects on the supply chain. The application of group purchasing, as in the case of the healthy drink manufacturer, has changed the balance of power between suppliers and manufacturers; this may lead to different purchasing terms. Through vertical integration, a collaboration approach, the flour supplier has a direct influence on the supply market for wheat, for example, in terms of the price and availability of wheat. The ability to source from different regions, a multiple suppliers approach, as in the case of the traditional store, has knock-on effects on local suppliers.

The result of this study also suggests that collusion among suppliers is a more common type of parallel interaction than general parallel interaction issues. It may be that regulations in Indonesia are inadequate and do not prevent unfair business practices, such as monopolies forming or business collusion. Power in a supply chain is one of the key elements that affect the balance in buyersupplier relationships; the balance of power could be changed because of parallel interaction issues or the implementation of a group purchasing strategy. Ethical issues, such as price fixing, are also identified in the context of managing supply chain uncertainty, as a result of the approaches employed by the supply chain members to change the balance of power to their advantage, especially when the existence of a business cartel is suspected.

\section{MANAGERIAL IMPLICATIONS}

This study has provided new insights for managers in managing uncertainty in their supply chain networks. Traditionally, managers focus on optimising serial interaction of companies from suppliers to customers in the supply network. The result of this study, however, point out that managing supply chain uncertainty is not only about tackling such serial issues, but also goes beyond this as there is also parallel interaction issues which are more unpredictable and challenging.

For example, collusion among suppliers is a more common type of parallel interaction issue 
identified in this study. This finding has managerial implication because of difficulties of managing it. As discussed in previous section, to cope with this unethical business practice, managers, where feasible, may need to consider a wide variety of strategies such as group purchasing, collaboration or multiple supplier approach in order to minimise the impact on supply chain performance.

As firms increase their supply chain activities with more suppliers and customers, managers would also generally expect an increased level of difficulties in managing parallel interaction. Empirical evidence of parallel interaction issues and how companies manage them, provided in this study, gives potential benefits to organisations to increase their knowledge about the uncertainty phenomena of the supply chain in which they operate. From a managerial standpoint, this evidence can help to identify and develop an effective way of reducing or coping with it.

\section{CONCLUSION}

Taken together, the results of analysis have enhanced understanding of parallel interaction in supply chain by providing empirical evidence to support previous studies and clarification to previous studies which lacked explanation or empirical evidence. The two types of parallel interactions, explained in the previous studies, were found in this study although the second type was more common. Parallel interaction is a source of uncertainty at supply chain level and is a difficult problem to manage. However, some companies in this study were identified of using strategies such as collaboration, group purchasing and multiple suppliers to effectively manage the issues caused by parallel interaction. 


\section{REFERENCES}

Achrol, R. (1997). Changes in the theory of interorganizational relations in marketing: Toward a network paradigm. Journal of the Academy of Marketing Science, 25(1), 56-71. http://doi.org/10.1007/BF02894509

Amit, S., Soundar, K., Mark, G., \& Nandini, R. U. (2005). Supply-chain networks: a complex adaptive systems perspective. International Journal of Production Research, 43(20), 4235-4265.

Ayres, L. (2008). Semi-Structured Interview. Thousand Oaks, USA: Sage Publications.

Barratt, M. (2004). Understanding the meaning of collaboration in the supply chain. Supply Chain Management: An International Journal, 9(1), 30-42. http://doi.org/10.1108/13598540410517566

Beamon, B. M. (1999). Measuring supply chain performance. International Journal of Operations and Production Management, 19(3), 275-292.

Bellamy, M. A., \& Basole, R. C. (2013). Network analysis of supply chain systems: A systematic review and future research. Systems Engineering, 16(2), 235-249.

Blecker, T., Kersten, W., \& Meyer, C. M. (2005). Development of an Approach for Analyzing Supply Chain Complexity. In Proceedings from The International Mass Customization Meeting 2005 (IMCM'05) (pp. 47-59). Klagenfurt/Austria.

Borgatti, S. P., \& Li, X. (2009). On Social Network Analysis in a Supply Chain Context*. Journal of Supply Chain Management, 45(2), 5-22.

Carter, C. R., Ellram, L. M., \& Tate, W. (2007). The Use of Social Network Analysis in Logistics Research. Journal of Business Logistics, 28(1), 137-168.

Choi, T. Y., Dooley, K. J., \& Rungtusanatham, M. (2001). Supply networks and complex adaptive systems: control versus emergence. Journal of Operations Management, 19(3), 351-366.

Cox, A. (1999). Power, value and supply chain management. Supply Chain Management, 4(4), 167.

Creswell, J. W. (2003). Research Design: Qualitative, quantitative, and mixed method approaches (Vol. 2). Sage Publications, Inc.

Eisenhardt, K. M., \& Graebner, M. E. (2007). Theory Building From Cases: Opportunities and Challenges. The Academy of Management Journal (AMJ), 50(1), 25-32.

Ellram, L. M. (1996). The use of the case study method in logistics research. Journal of Business Logistics, 17(2), 93.

Hearnshaw, E. J., \& Wilson, M. M. (2013). A complex network approach to supply chain network theory. International Journal of Operations \& Production Management, 33(4), 442-469.

Hesping, F. H., \& Schiele, H. (2015). Purchasing strategy development: A multi-level review. Journal of Purchasing and Supply Management, 21(2), 138-150. http://doi.org/10.1016/j.pursup.2014.12.005

Hingley, M. K. (2005). Power Imbalance in UK Agri-Food Supply Channels: Learning to Live with the Supermarkets. Journal of Marketing Management, 21, 63-88.

Holweg, M., \& Pil, F. K. (2008). Theoretical perspectives on the coordination of supply chains. Journal of Operations Management, 26(3), 389-406.

Huang, M.-C., Yen, G.-F., \& Liu, T.-C. (2014). Reexamining supply chain integration and the supplier\&amp;apos;s performance relationships under uncertainty. Supply Chain Management: An International Journal, 19(1), 64-78. http://doi.org/10.1108/ SCM-04-2013-0114

Ireland, R. D., \& Webb, J. W. (2007). A multi-theoretic perspective on trust and power in strategic supply chains. Special Issue Evolution of the Field of Operations Management SI/ Special Issue Organisation Theory and Supply Chain Management, 25(2), 482-497. http://doi.org/10.1016/j.jom.2006.05.004

Jones, C., Hesterly, W. S., \& Borgatti, S. P. (1997). A General Theory of Network Governance: Exchange Conditions and Social Mechanisms. Academy of Management Review, 22(4), 911-945.

Katz, M. L., \& Shapiro, C. (1985). Network externalities, competition, and compatibility. The American Economic Review, $424-440$.

Kim, Y., Choi, T. Y., Yan, T., \& Dooley, K. (2011). Structural investigation of supply networks: A social network analysis approach. Journal of Operations Management, 29(3), 194-211. http://doi.org/10.1016/j.jom.2010.11.001

Krajewski, L., Wei, J., \& Tang, L. (2005). Responding to schedule changes in build-to-order supply chains. Journal of Operations Management, 23(5), 452-469. http://doi.org/10.1016/j.jom.2004.10.006

Lambert, D. M., \& Cooper, M. C. (2000). Issues in Supply Chain Management. Industrial Marketing Management, 29(1), 65-83.

Lazzarini, S. G., Chaddad, F. R., \& Cook, M. L. (2001). Integrating supply chain and network analyses: the study of netchains. Journal on Chain and Network Science, 1(1), 7-22.

Maloni, M., \& Brown, M. (2006). Corporate Social Responsibility in the Supply Chain: An Application in the Food Industry. Journal of Business Ethics, 68(1), 35-52.

McAdam, R., \& McCormack, D. (2001). Integrating business processes for global alignment and supply chain management. 
Business Process Management Journal, 7(2), 113-130. http://doi.org/10.1108/14637150110389696

Munson, C. L., Rosenblatt, M. J., \& Rosenblatt, Z. (1999). The use and abuse of power in supply chains. Business Horizons, 42(1), 55-65. http://doi.org/10.1016/S0007-6813(99)80049-4

Olsen, R. F., \& Ellram, L. M. (1997). A portfolio approach to supplier relationships. Industrial Marketing Management, 26(2), 101-113.

Pilbeam, C., Alvarez, G., \& Wilson, H. (2012). The governance of supply networks: a systematic literature review. Supply Chain Management: An International Journal, 17(4), 358-376. http://doi.org/10.1108/13598541211246512

Prater, E. (2005). A framework for understanding the interaction of uncertainty and information systems on supply chains. International Journal of Physical Distribution \& Logistics Management, 35(7/8), 524.

Quayle, M. (2003). A study of supply chain management practice in UK industrial SMEs. Supply Chain Management, 8(1), 79.

Reiner, G., \& Trcka, M. (2004). Customized supply chain design: Problems and alternatives for a production company in the food industry. A simulation based analysis. International Journal of Production Economics, 89(2), $217-229$.

Riis, J. O., Johansen, J., Waehrens, B. V., \& Englyst, L. (2007). Strategic roles of manufacturing. Journal of Manufacturing Technology Management, 18, 933-948. http://doi.org/10.1108/17410380710828262

Rodrigues, V. S., Stantchev, D., Potter, A., Naim, M., \& Whiteing, A. (2008). Establishing a transport operation focused uncertainty model for the supply chain. International Journal of Physical Distribution \& Logistics Management, 38(5), 388-411.

Sarkis, J., Zhu, Q., \& Lai, K. (2011). An organizational theoretic review of green supply chain management literature. International Journal of Production Economics, 130(1), 1-15. http://doi.org/10.1016/j.ijpe.2010.11.010

Sheffi, Y. (2001). Supply chain management under the threat of international terrorism. The International Journal of Logistics Management, 12(2), 1-11.

Shou, Y., Feng, Y., Zheng, J., Wang, G., \& Yeboah, N. E. (2013). Power source and its effect on customer-supplier relationships: An empirical study in Yangtze River Delta. International Journal of Production Economics, (0). http://doi.org/10.1016/j. ijpe.2013.03.003

Smeltzer, L. R., \& Siferd, S. P. (1998). Proactive Supply Management: The Management of Risk. International Journal of Purchasing and Materials Management, 34(4), 38-45. http://doi.org/10.1111/j.1745-493X.1998.tb00040.x

Taylor, D. H. (2006). Strategic considerations in the development of lean agri-food supply chains: a case study of the UK pork sector. Supply Chain Management, 11(3), 271.

Thun, J.-H., Drüke, M., \& Hoenig, D. (2011). Managing uncertainty - an empirical analysis of supply chain risk management in small and medium-sized enterprises. International Journal of Production Research, 49(18), 5511-5525. http://doi.org/10 $.1080 / 00207543.2011 .563901$

Vachon, S., Halley, A., \& Beaulieu, M. (2009). Aligning competitive priorities in the supply chain: the role of interactions with suppliers. International Journal of Operations \& Production Management, 29(4), 322-340. http://doi. org/10.1108/01443570910945800

Vorst, J. G. A. J. van der, \& Beulens, A. J. M. (2002). Identifying sources of uncertainty to generate supply chain redesign strategies. International Journal of Physical Distribution \& Logistics Management, 32(6), 409.

Webb, G. S. (2007). Supply Chain Complexity: Impact and Management. Retrieved from http://marriottschool.byu.edu/emp/ BMS/Documents/Scott\%20Webb\%20Paper.pdf

Wilding, R. (1998). The supply chain complexity triangle. International Journal of Physical Distribution \& Logistics Management, $28(8), 599$.

Wu, I.-L., Chuang, C.-H., \& Hsu, C.-H. (2014). Information sharing and collaborative behaviors in enabling supply chain performance: A social exchange perspective. International Journal of Production Economics, 148, 122-132. http://doi. org/10.1016/j.ijpe.2013.09.016 